\begin{tabular}{ll}
\hline \hline MINING AND METALLURGY INSTITUTE BOR & ISSN: 2334-8836 \\
& UDK: 622 \\
\hline \hline
\end{tabular}

UDK: $621.791 .77(045)=20$

DOI:10.5937/MMEB1304121M

Miroslav S. Milićević, Tatjana M. Jovanović, Valentina M. Nejkovic ${ }^{* * *}$

\title{
HIGH ENERGETIC EFFICIENCY OF HF INDUCTIVE WELDING
}

\begin{abstract}
This paper deals with a new impeder for HF inductive welding of steel tubes. Experimental researches were carried out on generators with impeders made of ferrite. The authors of paper introduce magneto dielectric FA-USA instead of ferrite, thus projecting a new impeder. Based on many years of experimental research with the new impeders, the solid energetic savings were achieved in welding compared with various ferrite and other impeders. Savings and welding with lesser power in the case of new impeders make it possible to increase the production rate of line for welded tubes.
\end{abstract}

Keywords: efficiency, energy, power, welding, frequency, impeder, investigation

\section{INTRODUCTION}

This paper deals with projection and realization of a new impeder for $\mathrm{HF}$ inductive welding of steel tubes aiming to achieving the energetic savings. The idea of welding tubes using HF currents has a long and wide developmental path in the world $[1,5]$. There are two methods with $\mathrm{HF}$ welding, and these are contact and inductive, differing among themselves in as much the way the electromagnetic energy is distributed from the generator to the edges of steel strip which is being welded. The welding method is chosen on the basis of production program as well as on the strategy of manufacturer of generators.

This paper will present the results achieved with HF inductive welding. The research was done on lamp generators with frequencies of 400-450 kHz.

Generators for inductive welding consist of HV transformers, a high voltage rectifier, an oscillator with a lamp, a transformer for impedance adaptation, an auxiliary inductor and an inductor itself. Power regulation is done through thyristor voltage regulators, connected in the primary of HV transformer. Regulated voltage of the secondary after rectification is an anode voltage for an oscillator.

The final part of generator for welding the tubes is shown in Figure 1.

\footnotetext{
* Bulevar Nemanjića 33/39, 18000 Niš; e-mail: lavmiro@eunet.rs

*** Faculty of Electronic Engineering, Niš
} 


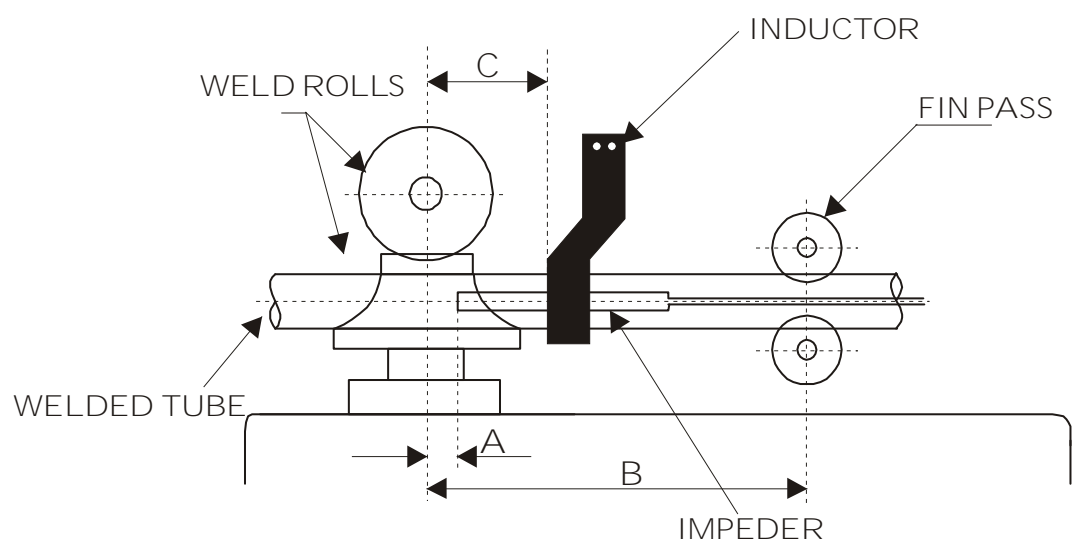

Figure 1 A detail of device for $H F$ inductive welding

The inductor is connected through the auxiliary inductor to the transformer secondary for adaptation. Inside the inductor, there is a formed tube made of steel strip. By means of rollers for welding, a necessary pressure is made onto the edges of strip, which are heated up to melting. By heating and pressing the edges of steel strip by forging, the connection is made and the tube is thus welded.

The impeder is built-in inside the steel tube, in the zone below inductor. Function of the impeder is to decrease the current in the internal and external contour of tube, while it increases the inductive current in so called "V" loop. Current on the resistance of steel strip causes heating, so that in the contact point "V" loop melting occurs. Melting realizing the required pressure on the rollers, has resulted in welded edges of strip, or welded steel tube.

View of details the "V" loop of steel tube with the contact point of connection and characteristic currents is shown in Figure 2, the current on pipe exterior, electricity inside the pipe and welding current in the "V" loop.

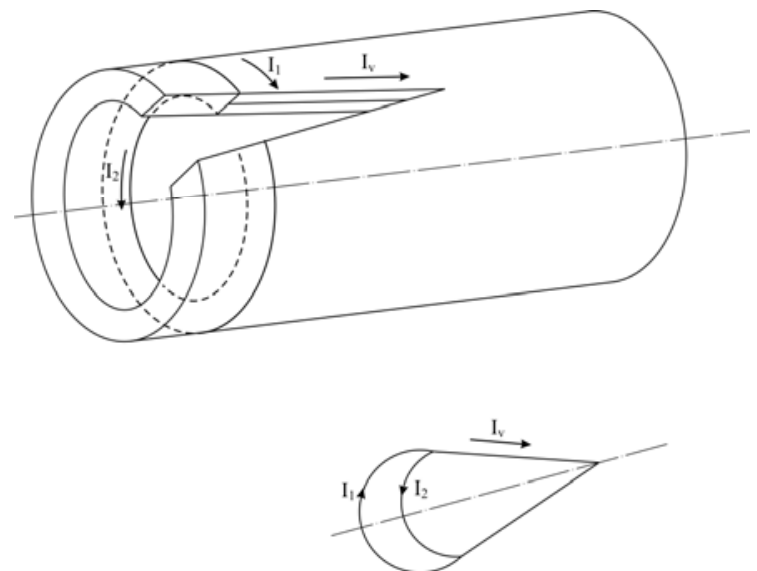

Figure 2 View of details of the "V loop" with characteristic currents 
In the view of heating tube, the current $I_{v}$ is the main welding current. Practically, the current distribution in Figure 2 will be made depending on the construction of impeder its electromagnetic characteristics. Using the magneto dielectric material, instead the previously used ferrites, results in optimum energy distribution in the weld zone. Therefore, the optimization is done by reducing the required welding power, because the flux is more properly distributed by induction from inducer, the losses are reduced, what makes the solution more original.

Impeder is made of a protective epoxy tube, which has a connector for cooling the fluid, into which, up to now, a ferrite core as a magneto conductor was placed. Dimensions in Figure 1 are determined by each manufacturer of generators, as well as by generator user itself. It is up to the researchers to find out better results.

There are many papers and projects which were focused on improvements the impeder which is actually a part of electromagnetic circuit in the process of energy emitting aiming at tube welding. In this paper, the researches were carried out on tubes with diameters of 17-48 $\mathrm{mm}$, the welding on them was done with ferrite and new impeders. The new impeders now have the magneto dielectric of the type Fluxtrol instead of ferrite, and in this way, the required power for welding is much saved. The inductive method for this kind of tube diameter range is affirmed and proven as very suitable for production.

\section{INVESTIGATION THE NEW IMPEDER}

Analysis and long-term research have proven that one of the central places in $\mathrm{HF}$ welding belongs to the impeder. The authors of the paper have, through research, introduced a new impeder into HF welding with the difference, as compared to the ferrite impeder, is in ferrite replacement by the magneto dielectric material.

Table 1 shows the characteristics of magnetodielectric of the firm Fluxtrol (MDM) out of which the new impeder was realized. Experiments and investigations of the new impeders were went smoothly from Fluxtrol F, Fluxtrol B, Ferrotron 559, and no energetic savings were achieved.

Table 1 Characteristics of magnetodielectric

\begin{tabular}{|c|c|c|c|c|c|}
\hline \multirow{2}{*}{$\begin{array}{c}\text { MDM } \\
\text { materials }\end{array}$} & $\mathbf{F}$ & B & C & $\mathbf{A}^{\prime}$ & A \\
\cline { 2 - 6 } & $13 \div 14$ & $23 \div 25$ & 18 & $30 \div 50$ & $60 \div 120$ \\
\hline Permeability & $>100$ & $20 \div 40$ & 250 & & $0,5 \div 1$ \\
\hline El. Res. $[\mathrm{k} \Omega \mathrm{cm}]$ & $5 \div 5,2$ & $5,8 \div 5,9$ & $3,9 \div 4$ & $6 \div 6,2$ & $6,8 \div 7,1$ \\
\hline Spec. grav. $\left[\mathrm{gr} / \mathrm{cm}^{3}\right]$ & & & & 1,6 \\
\hline Saturation $\mathrm{B}_{\mathrm{s}}[\mathrm{T}]$ & 0,4 & & & \\
\hline
\end{tabular}

Much better results were achieved applying the impeder of Fluxtrol A. The best results, in terms of energy savings, were achieved using magneto dielectric type $\mathrm{A}$, so that it became the optimal solution of a new impeder.

Figure 3 represents the new impeders where, out of the impeder tube, magneto- dielectrics can be seen of the square shaped cross-section just before the final closing of impeder. Connection for hose can be seen where the cooling fluid circulates and which takes away the excessive heat. Completely finished impeders are shown in Figure 4 and as such are ready for welding. 


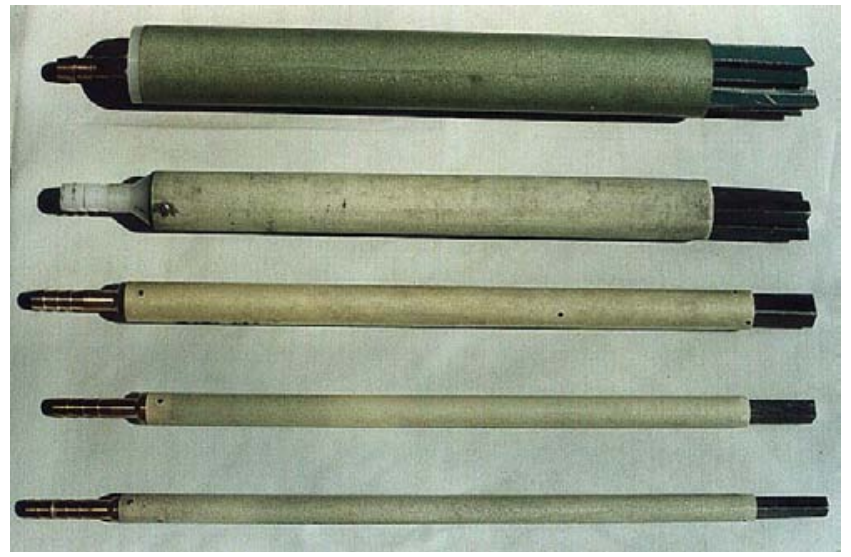

Figure 3 Epoxy tubes of the new impeder with magneto dielectric FA before closing

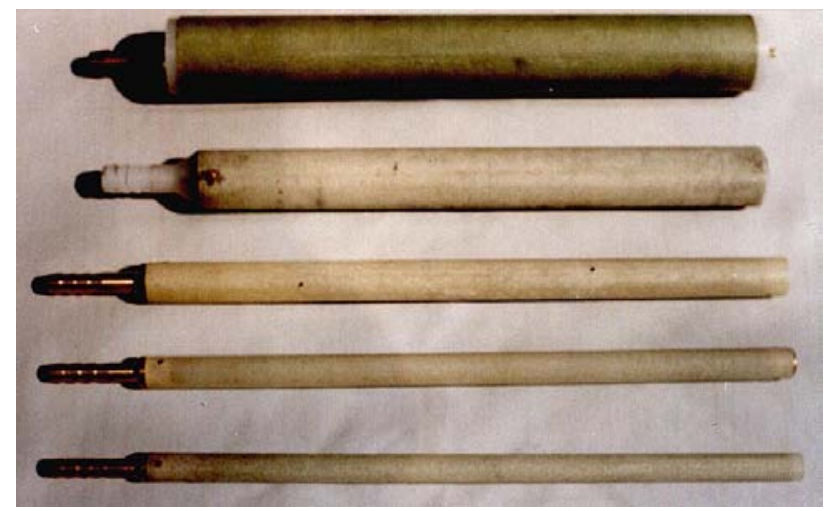

Figure 4 Completely finished new impeder

To evaluate the effectiveness of impeder, the well known criteria will be used from [1], where the specific power is taken $[\mathrm{kW} / \mathrm{mm}(\mathrm{m} / \mathrm{min})]$ in a function of production rate $[\mathrm{m} / \mathrm{min}]$. The criterion from [6] will be also used where in welding, the heating coefficient $[\mathrm{kW} / \mathrm{m} / \mathrm{min}]$ in the function of rate will be followed. The authors of this paper have introduced a new criterion where the energy spending is followed per ton of produced tube $[\mathrm{kWh} / \mathrm{t}]$, which is in the function of production rate $[\mathrm{m} / \mathrm{min}]$.

To such a good impeder, the authors of the paper oppose a new impeder with magneto dielectric $[7,8]$, and after several years of research and experiments, they have found out that a new impeder uses less of needed power for welding, which the numeric results will also confirm.

In order to carry out the strict tests and comparisons, through the long-time research in the field of welding, the best referent impeder with ferrites was defined. The referent impeder, on the basis of the results from [914] from the experiments, is the impeder with TDK ferrites.

\subsection{Results of the experimental researches}

The initial experiments were carried out with magneto dielectrics of the type 
Fluxtrol F, Fluxtrol B and Ferrotron 559; nevertheless, impeders with these materials did not save any power. Some better results were achieved applying the impeders with Fluxtrol A' material, where there are energy savings as compared to TDK ferrite impeder. However, as these results are worse than those from [6], where some special impeders were presented, any analysis will not be done.

After many years of experimental research, the authors of the paper have found out that the impeder with Fluxtrol A material gives the best results, so all results will be related to this new impeder. Due to the efficiency, the steel tube with, diameter of 21.6 x $2.65 \mathrm{~mm}$, will be adopted here as the representative, and all results of power saving will be related to the above mentioned tube.

Over a longer period of time, and many times, the production of a steel tube with diameter of $21.6 \mathrm{~mm}$ and wall thickness of $2.65 \mathrm{~mm}$, was monitored. Aiming at analyzing the energy savings, Table 2 shows the data for power from generator rectifiers for ferrite and a new impeder for various production rates.

Table 2 Comparative values of rectifier powers for ferrite and a new impeder and achieved savings in the function of rate

\begin{tabular}{|c|c|c|c|}
\hline $\mathbf{v}[\mathbf{m} / \mathbf{m i n}]$ & $\mathbf{P}_{\mathbf{a}}[\mathbf{k W}]$ & $\mathbf{P}_{\mathbf{b}}[\mathbf{k W}]$ & $\delta=\frac{\mathrm{P}_{\mathrm{a}}-\mathrm{P}_{\mathrm{b}}}{\mathrm{P}_{\mathrm{a}}}$ \\
\hline 10 & 60 & 44 & 24 \\
\hline 20 & 89 & 58 & 35 \\
\hline 30 & 120 & 72 & 40 \\
\hline 40 & 148 & 85 & 43 \\
\hline 50 & 177 & 98 & 45 \\
\hline 60 & 205 & 112 & 45 \\
\hline 70 & 225 & 126 & 45 \\
\hline
\end{tabular}

$\mathrm{P}_{\mathrm{a}}$ in Table 2 presents the power for ferrite impeder in $[\mathrm{kW}]$, while $\mathrm{P}_{\mathrm{b}}$ refers to the new FA impeder.

Defined percentage savings in welding power is

$$
\delta=\frac{\mathrm{P}_{\mathrm{a}}-\mathrm{P}_{\mathrm{b}}}{\mathrm{P}_{\mathrm{a}}} 100 \quad[\%],
$$

that represents the percentage of lesser expenditure spending of a new impeder as compared with ferrite impeder, what for selected tube at higher rate gives $45 \%$.

For graphic presentation, Figure 5 presents the function where rectifier power is shown on ordinate, curve "a" for ferrite impeder and curve " $b$ " for a new impeder, in the function of production rate, where saving of needed welding power is clearly seen.
Figure 6 shows saving as per relation (1) in the function of welding rate.

It can be concluded that the saving is lesser with lower rates, while the optimum wel-ding with new impeders is with rates of

$$
\mathrm{v} \geq 40[\mathrm{~m} / \mathrm{min}]
$$

Summarizing the results on production tube with diameter of $21.6 \mathrm{~mm}$, where the effect of a new FA impeder is compared to TDK ferrite impeder, the conclusion can be drawn that a significant energy saving is got with a new impeder in the needed power for welding. The used power of new impeder from generator of rectifier is $45 \%$ less as compared with ferrite impeder consumption. 


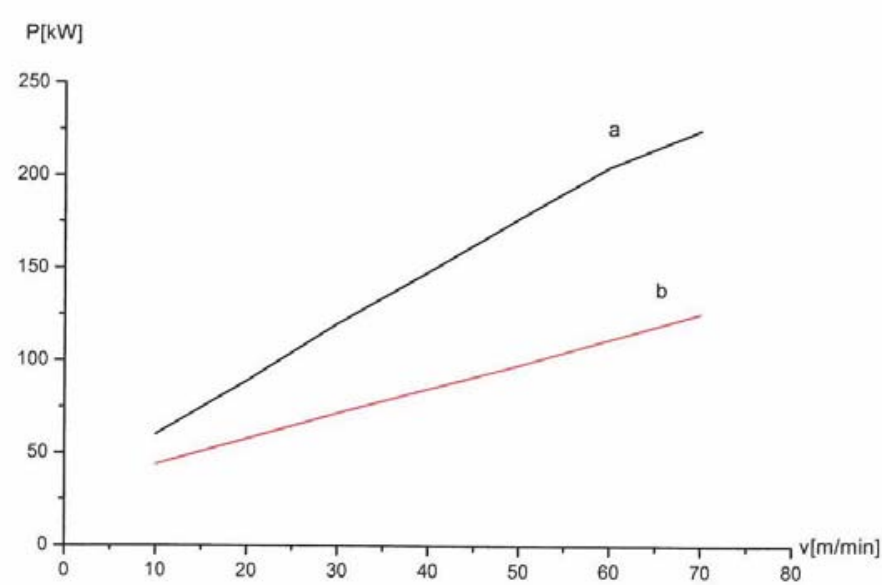

Figure 5 Power from rectifier in the function of production rate (a-TDK fer.imp, b-FA impeder)

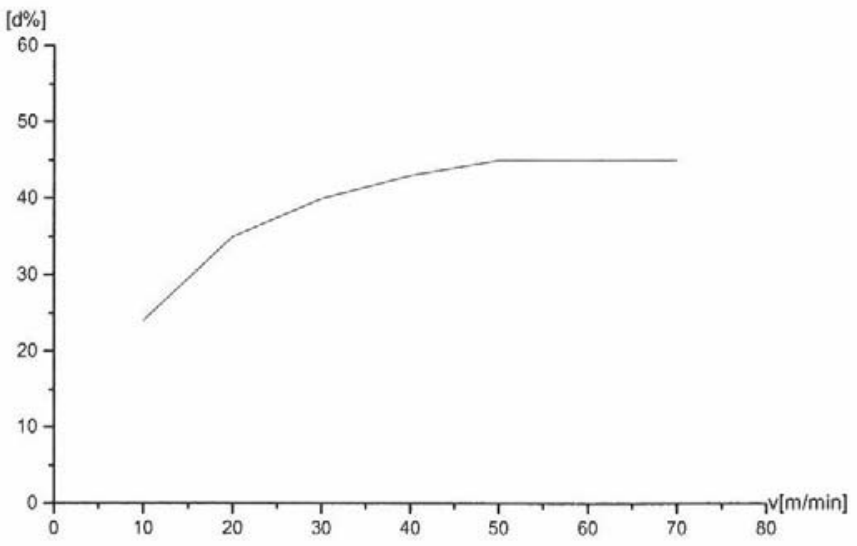

Figure 6 Relative percentual power saving in the function of production speed

The experiment was carried out with impeders with diameter of $12 \mathrm{~mm}$, while the ferrite core in ferrite impeder was of the star like cross-section with diameter of $10 \mathrm{~mm}$, while with the new FA impeder, the mate-rial was of the square crosssection $7 \times 7 \mathrm{~mm}$. Length of ferrite impeder was $200 \mathrm{~mm}$, while length of the new impeder was $150 \mathrm{~mm}$.

The welded tube was, in both cases, mechanically tested under the pressure on flattening. The weld with the new impeder and complete flattening was not opened, which is not the case with ferrite impeder weld. A tube was broken on the basic material without any welds during many mechanical tests, even with testing with complete flattening. However, the weld that was the result of welding with the new FA impeder was highly scored by the Control Department of FAHOP according to the ISO Standard.

The obtained saving using the new impeder makes the production of significantly higher production rates, which results in the increase of productivity of technological lines for production the steel tubes. 


\subsection{Application of Criteria for Evaluation the Achieved Results}

The authors will use the already mentioned three criteria for evaluation the achieved results of the new FA impeder in

production a tube with diameter of $21.6 \mathrm{~mm}$.

Figure 7 presents dependence of spent energy per tone in the function of rate.

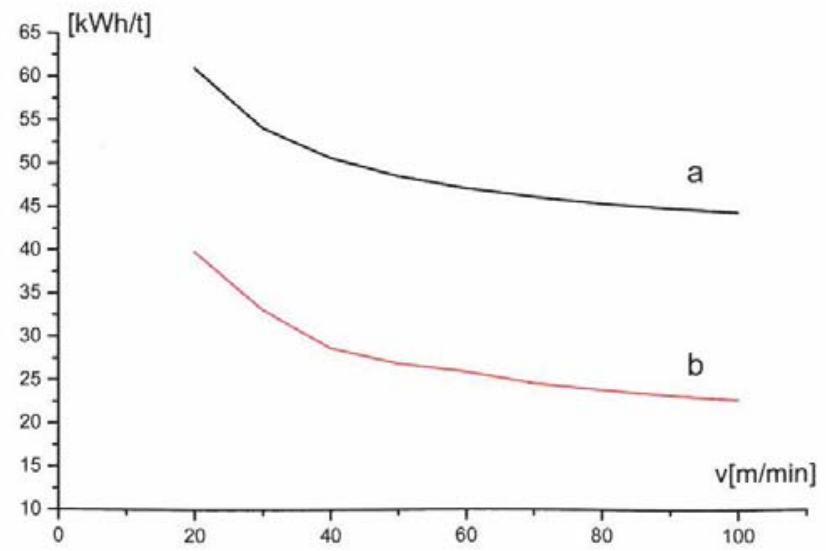

Figure 7 Energy consumption as per tone of tube in the function of production rate a) TDK ferrite impeder; b) FA impeder

Dependence of heat coefficient from [6] is presented in Figure 8.

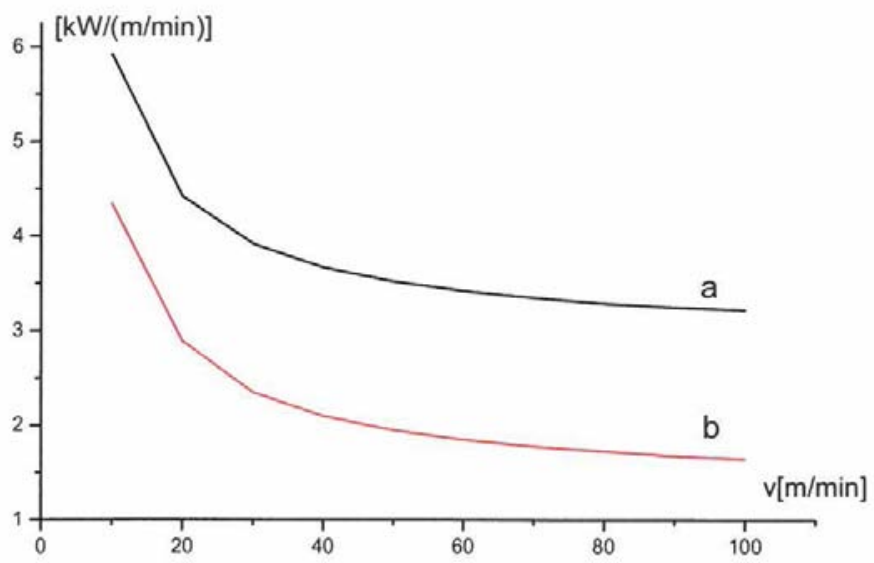

Figure 8 Heat coefficient in the function of the production speed (a-TDK ferrite impeder, $b$-FA impeder)

Graph of specific power as per [1] is presented in Figure 9. 


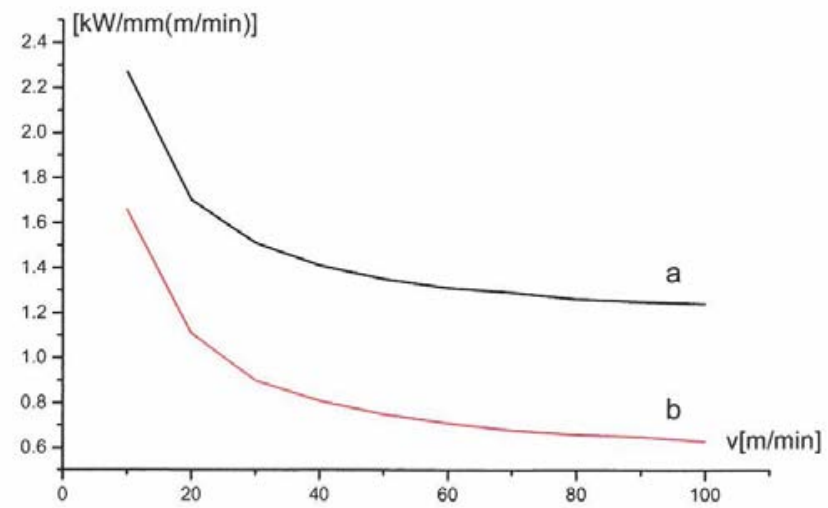

Figure 9 Specific power in the function of the production speed (a-TDK ferrite impeder, $b$-FA impeder)

The curve "a" corresponds to the ferrite impeder, while the curve "b" corresponds to the new FA impeder. It can be concluded that the new impeder is much more efficient what the above mentioned three criteria confirm. Two of these three criteria are used in literature as wellknown, while the one criterion is introduced by the authors of the paper as the original and new.

Besides the mentioned energy savings of $45 \%$ using the new FA impeder, in comparison to the best TDK ferrite impeder, applying the above mentioned three criteria, all mentioned criteria give a good evaluation of efficiency the new impeder application. The authors to the useful conclusion, through their researches, that it is more effective to weld at rates higher than

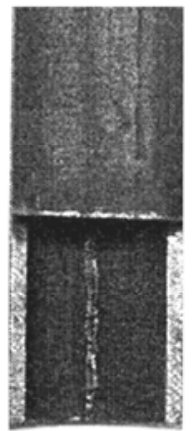

$40 \mathrm{~m} / \mathrm{min}$ when the optimum is achieved. Optimum is achieved when the value from (1) reaches the asymptote, which can also be applied with other criteria. The authors from [6] do not perceive these conclusions, but give the results for rates that are higher than or equal to $50 \mathrm{~m} / \mathrm{min}$.

Figure 10 illustrates the photos of original inner welds, so called penetration with the ferrite impeder and new FA impeder. The first photo was obtained with ferrite impeder, and the second with the new FA impeder. The inner weld was obtained with the new impeder with less superelevations, it is narrower and more continuous, and mechanical tests of flattening further confirm this statement by the fact that the weld is considerably more persistent.

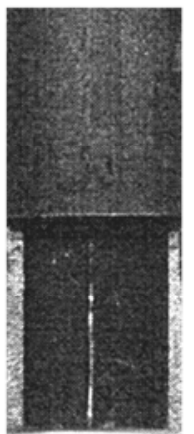

Figure 10 Weld in the interior of the pipe for the ferrite and new impeder 
The new impeder with FA magneto dielectric will be compared to the results given in [6]. The paper presents the results of application the special impeders with amorphous foils and 3\% Si foil, used with the ferrite impeder from Japan.

The authors of this paper will, for the aim of clearance, present the comparative characteristics of their scientific - research results and results from reference
[6] In Table 3. Applying all three criteria it can be concluded that the new FA impeder is better. The power saving in [6]is $32 \%$, which in comparison to the new FA impeder FA of $45 \%$ gives the conclusion that the solution of the author of this work is more efficient as per $41 \%$. It should be added that the solution, given in this paper, is cheaper than the aforementioned.

Table 3 Presentation the results of comparable criteria for TDK and a new FA impeder and results from [6]

\begin{tabular}{|l|c|c|c|c|}
\hline \multicolumn{1}{|c|}{ Criteria } & $\frac{\mathrm{kWh}}{\mathrm{t}}$ & $\frac{\mathrm{kW}}{\mathrm{mm}(\mathrm{m} / \mathrm{min})}$ & $\frac{\mathrm{kW}}{\mathrm{m} / \mathrm{min}}$ & $\begin{array}{c}\text { Length } \\
{[\mathbf{m m}]}\end{array}$ \\
\hline Impeder material & 83.3 & 3.57 & 15 & 400 \\
\hline Ferrite - [7] & 57.11 & 2.45 & 10.3 & 400 \\
\hline Ferrite - TDK & 50 & 1.35 & 3.52 & 200 \\
\hline Magn. diel. - FA & 27 & 0.75 & 1.95 & 150 \\
\hline
\end{tabular}

Applying the new impeder, energetic savings up to $45 \%$ are achieved in comparison to the ferrite impeder, which justifies the research results The new impeder also gives savings when compared to some special impeders from [6], so a very useful application is opened with impeders made of magneto dielectrics.

\section{CONCLUSION}

The main aim of the authors of this paper is to design and investigate a new impeder with magneto dielectrics which will have significant energy savings in power while welded in relation to TDK ferrite impeder. Based on many years of experimental researches, among the magneto dielectrics of the firm Fluxtrol, the authors have found out that an optimal material is Fluxtrol A for impeder production and this is the way how the new impeder is made.

It has been shown and proven that the application of the new impeder brings the significant energetic savings as compared to ferrite impeders, as well as when compared to some special impeders. Applying the well known criteria and the newly introduced criterion, it is determined that the new impeder has better performances regarding to the ferrite impeder.

If the annual savings are calculated for the referent tube with diameter of $21.6 \mathrm{~mm}$, the clear financial saving is approx. $\$ 350,000$. The achieved saving of energy of $45 \%$ makes possible the increase of production, that is, the production rate of the steel tubes up to $90 \%$ what justifies the efforts of researchers.

Although the experiments were carried out with a lamp generator, the results change the aspect to the inductive method of welding for the range of researched diameters of tubes. The results also change the value of total efficiency coefficient of lamp generators for welding, from the point of view of input power and power which is given to the steel tube itself in the process of HF inductive welding.

The authors of the paper present to the qualified and scientific public the new solution for impeders with magneto dielectrics of the type Fluxtrol A, which, used in practice, brings many energy savings that are con 
firmed by the experimental results. Energetic savings make the possibilities of increasing the welding rate, and therefore the production of steel tubes, which implies an increase in productivity of technological lines for production of steel pipes.

\section{REFERENCES}

[1] Šamov N. A., Lunin V. I., Ivanov N. V.: 'Vysokočastotnaja svarka metalov' (Mašinostroenie, Leningrad, 1977), pp. 5-23.

[2] Guljajev D.: 'Soveršenstvovanie tehnologii proizvodstva i povišeniie kačestvo elektrosvarnyh trub' (Tehnika, Kiev, 1984), pp. 86-116.

[3] Nemkov V. S., Demidovich V. B. (1988) Theory of Induction Heating, Energy Publ., St. Petersburg, pp. 6-30

[4] Wright J. (1997) Principles of High Frequency Induction Tube Welding. Electronic Heating Equipment, Sumner Inc., pp. 1-8.

[5] Wade J. (1990), Effective Utilisation of Magnetic Flux Concentrators in Induction Heating at Commercial Heat Treating Plant., Industrial Heating, Vol. LVI, No. 2, Feb.1989, Fluxtrol Manufacturing Inc., pp. 14-16.

[6] Mitani K., Shibua-ku H., 'Impeder: 'How its Innovation and Design Impacts the Welding Processes'. The Eight Annual World Tube Congress, 912.11.1992, Chicago, Illinois, pp. 35-33.

[7] Rudnev I. V.: 'Induction Heat Treatment' (Steel Heat Treatment Handbook, New York, Basel, Hong Kong, 1997), pp.1-27.
[8] Fluxtrol Manufacturing: 'Magnetic Flux Concentrators for High Fre-quency Induction Heating'. Fluxtrol Manufacturing, MI-USA, 1996, pp. 1-45.

[9] Milićević M.: 'Avtomatičeskoe upravlenie processom indukcionnoi svarki trub s primeneniem mikro-EVM', $7^{\text {th }}$ Meždunarodnoja konferencija stran členov SEV i SFRJ po avtomatizacii proizvodstvenyh processov i upravlenija v černoi metalurgii, 1988, Ždanov, SSSR, pp. 1-10.

[10] Milićević M., Milićević V. (2001) Optimization of Energetic Parameters and Quality of HF Inductive Welding of Steel Pipes, XI International Symposium - Energetic Electronics Ee-2001, 31.10. - 2.11.2001, Novi Sad

[11] Milićević M., Milićević V., Milićević T. (2004), MDM Impeder for Improvement of Parameters and Quality of HF Inductive Welding, 36 ${ }^{\text {th }}$ International October Conference on Mining and Metallurgy, Bor, pp. 531-537.

[12] TDK: 'TDK Impeder Core'. Technical Documentation, Italy, 1999, pp. 1-37.

[13] 'Catalog Applications Guide', Electronic Heating Equipment, Inc., Impeders, Work Coils, Ferrite, Casing, 1998, Buckley-WA, pp. 1-20.

[14] Milićević M., The application of a New Formula of Nakaoka Coefficient in HF Inductive Welding, Journal of Mechanical Engineering, Faculty of Mechanical Engineering Ljubljana, Slovenia, No. 7-8, vol. 56, 2010, pp. 483-485. 


\begin{tabular}{ll}
\hline \hline INSTITUT ZA RUDARSTVO I METALURGIJU BOR & ISSN: 2334-8836 \\
& UDK: 622 \\
\hline \hline
\end{tabular}

\title{
VISOKA ENERGETSKA EFIKASNOST KOD VF INDUKTIVNOG ZAVARIVANJA
}

\begin{abstract}
Izvod
U ovom radu se opisuje nov impeder za VF induktivno zavarivanje čeličnih cevi. Eksperimentalna istraživanja su vršena na generatoru koji je imao feritne impedere. Autori rada umesto ferita uvode magnetodielektrik Fluxtrol FA USA projektujući time novo rešenje impedera. Na osnovu dužeg eksperimentalnog istraživanja sa novim impederima postignute su solidne energetske uštede pri zavarivanju u poređenju sa više različitih feritnih i drugih impedera. Ušteda i zavarivanje sa manjim snagama primenom novih impedera stvara mogućnost da se poveća proizvodna brzina linije za izradu čeličnih cevi.

Ključne reči: efikasnost, energija, snaga, zavarivanje, frekvencija, impeder, istraživanje
\end{abstract}

\section{UVOD}

Ovaj rad se bavi projektovanjem i realizacijom novog impedera za VF induktivno zavarivanje čeličnih cevi sa ciljem da se postigne energetska ušteda. Ideja da se cevi zavaruju VF strujama ima dug i veliki razvojni put u svetu [1-5]. Kod VF zavarivanja postoje dve metode i to kontaktna i induktivna, a koje se razlikuju po načinu predaje elektromagnetne energije sa generatora na ivice čelične take koje se zavaruju. Metoda zavarivanja se bira u zavisnosti od proizvodnog programa i same strategije proizvođača generatora.

U ovom radu će se prikazati rezultati koji su postignti kod VF induktivnog zavarivanja. Istraživanja su obavljena na generatorima sa cevima čije su frekvencije od $400-500 \mathrm{kHz}$.

Generatori za induktivno zavarivanje se sastoje od VN transformatora,ispravljača visokog napona, cevnog oscilatora, transformatora za prilagođenje impedanse, pomoćnog induktora i induktora. Regulacija snage se obavlja tiristorskim regulatorima napona koji su povezani u primaru $\mathrm{VN}$ transformatora. Regulisani napon sekundara posle ispravljanja čini anodni napon za napajanje oscilatora.

Završni i finalni deo generatora za zavarivanje cevi je prikazan na sl. 1.

\footnotetext{
* Bulevar Nemanjića 33/39, 18000 Niš; e-mail: lavmiro@eunet.rs

*** Elektronski fakultet u Nišu
} 


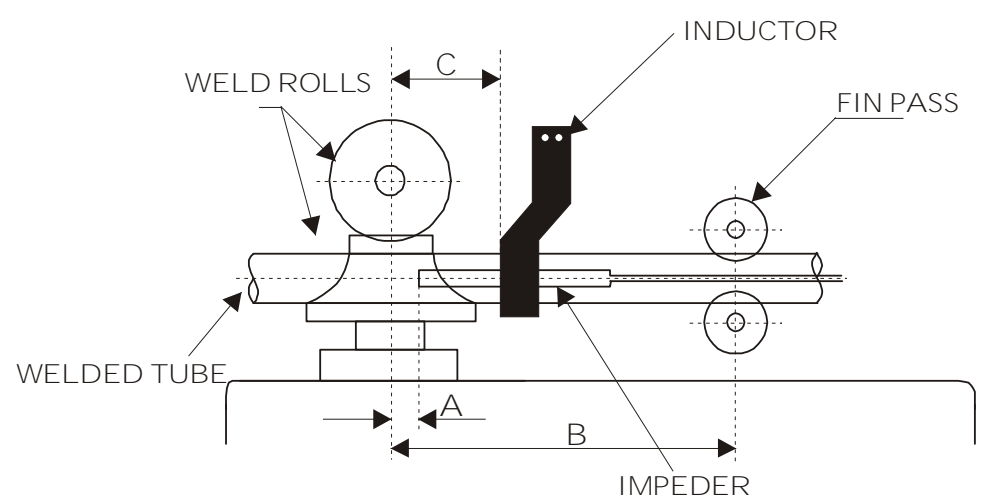

SI. 1. Detalj uređaja za VF induktivno zavarivanje

Induktor se povezuje preko pomoćnog induktora na sekundar transformatora za prilagođenje. Unutar induktora prolazi formirana cev od čelične trake. Valjcima za zavarivanje se ostvaruje potreban pritisak na ivice trake koje se zagrevaju do topljenja. Zagrevanjem i pritiskanjem ivica čelične trake, putem kovanja, se obavlja spajanje i time je cev zavarena.

Unutar čelične cevi, a u zoni ispod induktora, se ugrađuje impeder. Funkcija impedera je da smanji struje u unutrašnjoj i spoljašnjoj konturi cevi, a poveća indukovanu struju u tzv "V" petlji. Struja na otporu čelične trake izaziva grejanje tako da se u kontaktnoj tački "V" petlje vrši topljenje. Topljenje, o stvarivanjem potrebnog pritiska na valjcima, ima za posledicu zavarene ivice trake, odnosno zavarenu čeličnu cev.

Prikaz detalja "V" petlje čelične cevi sa kontaktnom tačkom spajanja i karakterističnim strujama je prikazan na sl. 2, struja po spoljašnosti cevi, struja po unutrašnjosti cevi i struja zavarivanja u "V" petlji.
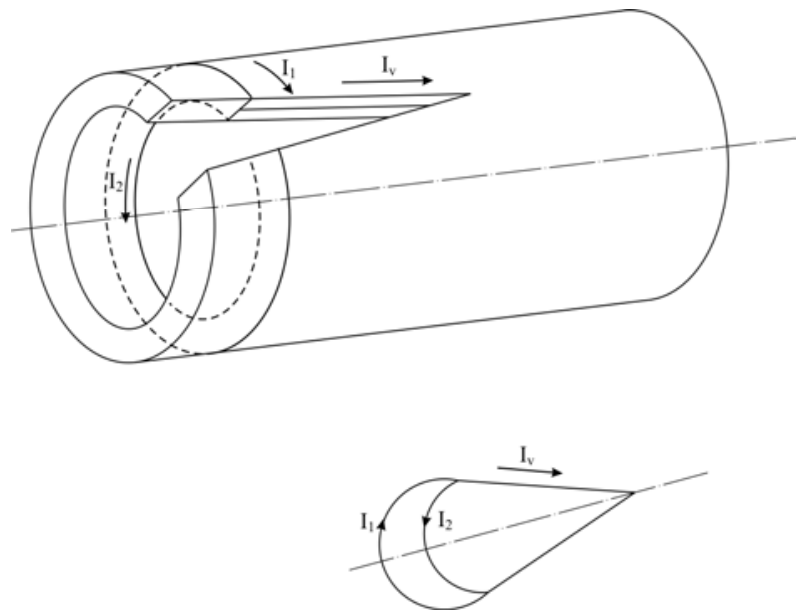

S1. 2. Prikaz detalja "V" petlje sa karakterističnim strujama 
U prikazu grejanja cevi struja $\mathrm{I}_{\mathrm{v}}$ predstavlja glavnu struju zavarivanja. Praktično raspodela struja sa sl. 2 će se vršiti zavisno od konstrukcije impedera i njegovih elektromagnetnih karakteristika. Upotrebom magnetodielektričnog materijala namesto do sada korišćenih ferita dobija se optimalna distribucija energije na zonu zavarivanja. Zato se vrši optimizacija smanjenjem potrebne snage zavarivanja, jer se fluks indukcijom iz induktora pravilnije raspoređuje, smanjuju se gubici, što rešenje čini originalnijim.

Impeder je sastavljen od zaštitne čaure, koja ima priključak za rashladnu tečnost, $\mathrm{u}$ koju je do sada smeštan ferit kao magnetoprovodnik. Dimenzije sa sl. 1 određuje svaki proizvođač generator, a i sam korisnik generatora. $\mathrm{Na}$ istraživačima je da iznalaženjem i kreativnim delovanjem postignu što bolje rezultate.

Postoji mnogo radova i projekata koji su usmeravani na poboljšanje impedera, koji je ustvari deo elektromagnetnog kola u procesu predaje energije u cilju zavarivanja čelične cevi. U ovom radu istraživanja su vršena na cevima prečnika 17 - 48 mm, i na kojima se zavarivalo feritnim i novim impederima. Novi impederi sada umesto ferita imaju magnetodielektrik tipa Fluxtrol, čime se dobija ušteda u potrebnoj snazi za zavarivanje. Za ovaj opseg dijametara cevi induktivna metoda se afirmiše i čini prikladnom za proizvodnju.

\section{ISTRAŽVANJE NOVOG IMPEDERA}

Analizom i dugogodišnjim istraživanjem je potvrđeno da jedno od centralnih mesta u VF zavarivanju pripada i impederu. Autori rada su istraživanjem uveli u VF zavarivanje nov impeder čija je razlika u odnosu na feritni impeder to što ferit zamenjuje magnetodielektričnim materijalom.

U tabeli 1 su prikazane karakteristike magnetodielektrika firme Fluxtrol (MDM) od kojih se realizuje i nov impeder. Eksperimenti i istraživanja novog impedera su tekli redom od Fluxtrola F, Fluxtrola b, Ferrotrona 559 i sa njima nije ostvarena energetska ušteda.

Tabela 1. Karakteristike magnetodielektrika

\begin{tabular}{|c|c|c|c|c|c|}
\hline \multirow{2}{*}{$\begin{array}{c}\text { MDM } \\
\text { magnetodielektrik }\end{array}$} & \multicolumn{5}{|c|}{ Tip magnetodielektrika Fluxtrol } \\
\cline { 2 - 6 } & $\mathbf{F}$ & $\mathbf{B}$ & $\mathbf{C}$ & $\mathbf{A}^{\prime}$ & $\mathbf{A}$ \\
\hline Permeabilnost & $13 \div 14$ & $23 \div 25$ & 18 & $30 \div 50$ & $60 \div 120$ \\
\hline El. otpor $[\mathrm{k} \Omega \mathrm{cm}]$ & $>100$ & $20 \div 40$ & 250 & & $0,5 \div 1$ \\
\hline Spec. težina $\left[\mathrm{gr} / \mathrm{cm}^{3}\right]$ & $5 \div 5,2$ & $5,8 \div 5,9$ & $3,9 \div 4$ & $6 \div 6,2$ & $6,8 \div 7,1$ \\
\hline Mag. indukcija $\mathrm{B}_{\mathrm{s}}[\mathrm{T}]$ & 0,4 & & & & 1,6 \\
\hline
\end{tabular}

Izvesno poboljšanje je ostvareno primenom impedera od Fluxtrola A'. Najbolji rezultati u smislu energetske uštede su postignuti primenom magnetodielektrika tipa A, tako da je on postao optimalno rešenje jednog novog impedera.

Na slici 3 su prikazni novi impederi, gde se van čaure impedera vide magneto- dielektrici ćiji je presek kvadratnog oblika, neposredno pred završno zatvaranje impedera. Vidi se priključak za crevo gde cirkuliše rashladni fluid radi odvođenja suvišne toplote. Kompletno završeni impederi su prikazani na sl. 4 i kao takvi su spremni za zavarivanje. 


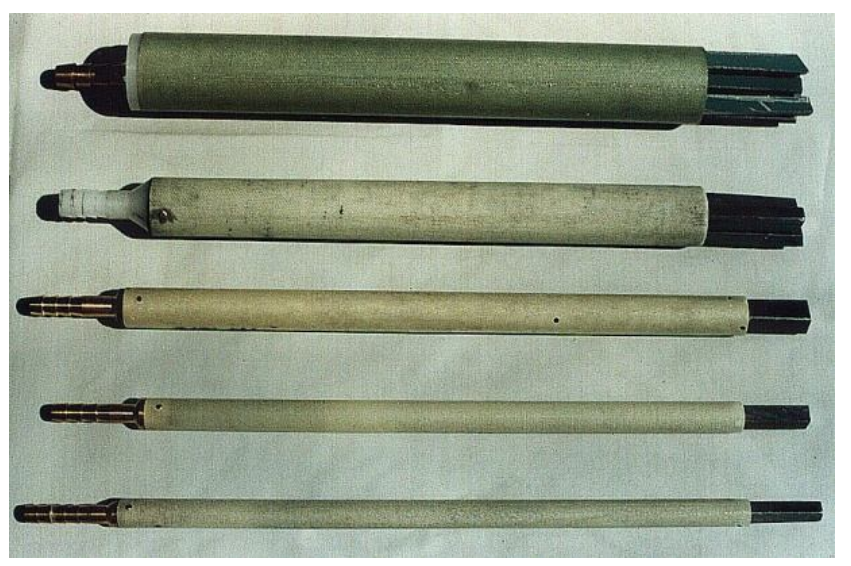

Sl. 3. Epoksidne čaure sa novim impederom od magnetodielektrika FluxtrolA pre zatvaranja

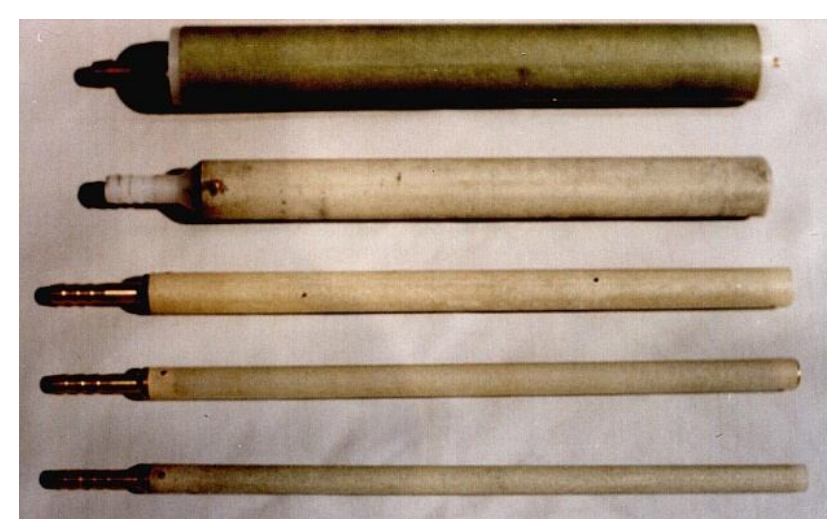

Sl. 4. Kompletno završen nov impeder

Radi ocene efikasnosti impedera koristiće se poznati kriterijum iz [1] gde se uzima specifična snaga $[\mathrm{kW} / \mathrm{mm}(\mathrm{m} / \mathrm{min})] \mathrm{u}$ funkciji proizvodne brzine $[\mathrm{m} / \mathrm{min}]$. Takođe će se koristiti kriterijum iz [6] gde se pri zavarivanju prati toplotni koeficijent $[\mathrm{kW} / \mathrm{m} / \mathrm{min}]$ u funkciji brzine. Autori rada uvode nov kriterijum gde se prati utrošak energije po toni proizvedene cevi $[\mathrm{kWh} / \mathrm{t}] \mathrm{u}$ funkciji proizvodne brzine [ $\mathrm{m} / \mathrm{min}]$.

Tako dobrom feritnom impederu, autori rada suprostavljaju nov impeder sa magnetodielektrikom [7,8], i posle nekoliko godina istraživanja i eksperimenata nalaze da nov impeder znatno manje troši potrebnu snagu za zavarivanje što će potvrditi i numerički rezultati.

Da bi se obavila stroga testiranja i upoređenja, kroz višegodišnje istraživanje u oblasti zavarivanja, definisan je najbolji referentni impeder sa feritima. Naš referentni impeder na bazi rezultata iz [9-14], i naših eksperimenata je impeder sa TDK feritima.

\subsection{Rezultati eksperimentalnih istraživanja}

Početni eksperimenti su obavljeni sa magnetodielektrikom tipa Fluxtrol F 
Fluxtrol B i Ferrotron 559, ali impederi sa ovim materijalima nisu dali uštedu u snazi. Nešto bolji rezultati su postignuti primenom impedera sa Fluxtrol A' materijalom, gde ima energetskih ušteda $u$ odnosu na TDK feritni impeder. No, kako su ti rezultati slabiji od rezultata iz [6], gde se prezentuju neki specijalni impederi tako da njih nećemo analizirati.

Posle višegodišnjih eksperimentalnih istraživanja autori rada su pronašli da najbolje rezultate daje impeder Fluxtrol A, tako da svi rezultati će se odnositi na ovaj nov impeder. Zbog efikasnosti, ovde će se usvojiti čelična cev prečnika 21,6x2,65 mm kao naš reprezent $\mathrm{i}$ svi rezultati uštede $u$ snazi odnosiće se na ovu pomenutu cev.

Kroz duži vremenski period, i više puta, je praćena proizvodnja čelične cevi prečnika $21,6 \mathrm{~mm}$ i debljina zida $2,65 \mathrm{~mm}$. Radi analize energetskih ušteda $\mathrm{u}$ tabeli $\mathrm{T}_{2}$ su prikazani podaci za snagu iz ispravljača generatora za feritni i nov impeder za različite proizvodne brzine.

Tabela 2. Uporedne vrednosti snaga iz ispravljača za feritni i nov impeder i postignuta ušteda u funkciji brzine

\begin{tabular}{|c|c|c|c|}
\hline $\mathbf{v}[\mathbf{m} / \mathbf{m i n}]$ & $\mathbf{P}_{\mathbf{a}}[\mathbf{k W}]$ & $\mathbf{P}_{\mathbf{b}}[\mathbf{k W}]$ & $\delta=\frac{\mathrm{P}_{\mathrm{a}}-\mathrm{P}_{\mathrm{b}}}{\mathrm{P}_{\mathrm{a}}}$ \\
\hline 10 & 60 & 44 & 24 \\
\hline 20 & 89 & 58 & 35 \\
\hline 30 & 120 & 72 & 40 \\
\hline 40 & 148 & 85 & 43 \\
\hline 50 & 177 & 98 & 45 \\
\hline 60 & 205 & 112 & 45 \\
\hline 70 & 225 & 126 & 45 \\
\hline
\end{tabular}

$\mathrm{U}$ tabeli $\mathrm{T}_{2} \mathrm{P}_{\mathrm{a}}$ predstavlja snagu $\mathrm{u}[\mathrm{kW}]$ za feritni impeder, $\mathrm{a} \mathrm{P}_{\mathrm{b}}$ za nov impeder FA.

Definisana procentualna ušteda u snazi zavarivanja je:

$$
\delta=\frac{\mathrm{P}_{\mathrm{a}}-\mathrm{P}_{\mathrm{b}}}{\mathrm{P}_{\mathrm{a}}} 100[\%],
$$

koja predstavlja za koliko procenata manje troši nov impeder u odnosu na feritni impeder, što za izabranu cev pri većoj brzini daje $45 \%$.

Radi grafičke prezentacije na sl. 5 je prikazana zavisnost, gde se na ordinati nanose snage iz ispravljača, kriva "a" za feritni impeder i "b" za nov impeder, u funkciji proizvodne brzine, gde se jasno vidi ušteda u potrebnoj snazi zavarivanja.
Slika 6 prikazuje uštedu po relaciji (1) u funkciji brzine zavarivanja. Zaključuje se da je ušteda manja na malim brzinama, a da je optimalno zavarivati novim impederom na brzinama:

$$
\mathrm{v} \geq 40 \quad[\mathrm{~m} / \mathrm{min}]
$$

Rezimirajući rezultate na proizvodnji cevi prečnika 21,6 $\mathrm{mm}$, gde se upoređuje efekat novog FA impedera u odnosu na TDK feritni impeder, zaključak je da se novim impederom dobija znatna energetska ušteda u potrebnoj snazi za zavarivanje. Za $45 \%$ manje se angažuje snaga iz ispravljača generatora pri korišćenju novog impedera u odnosu na potrošnju sa feritnim impederom. 


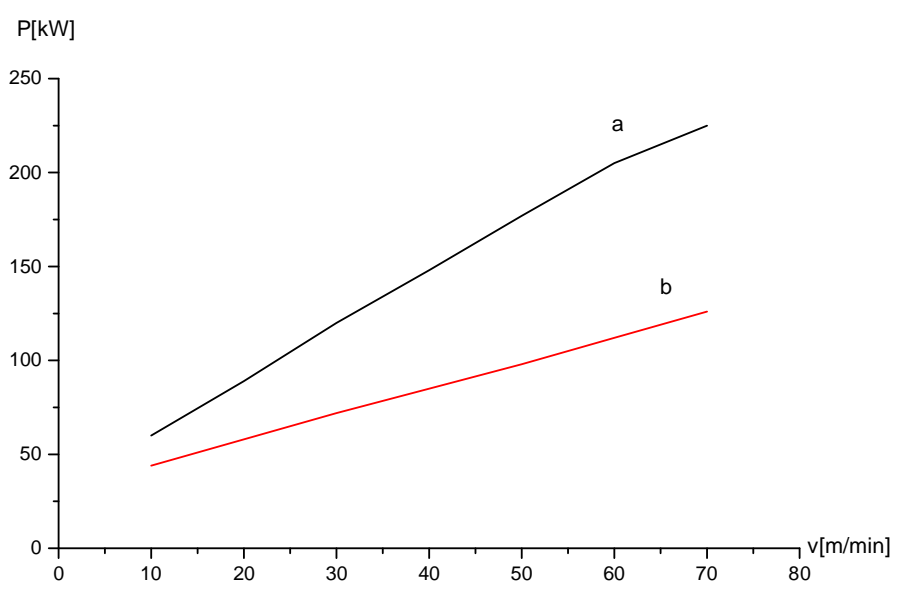

Sl. 5. Snage iz ispravljača u funkciji proizvodne brzine (a-TDKfer.imp., b-FA impeder)

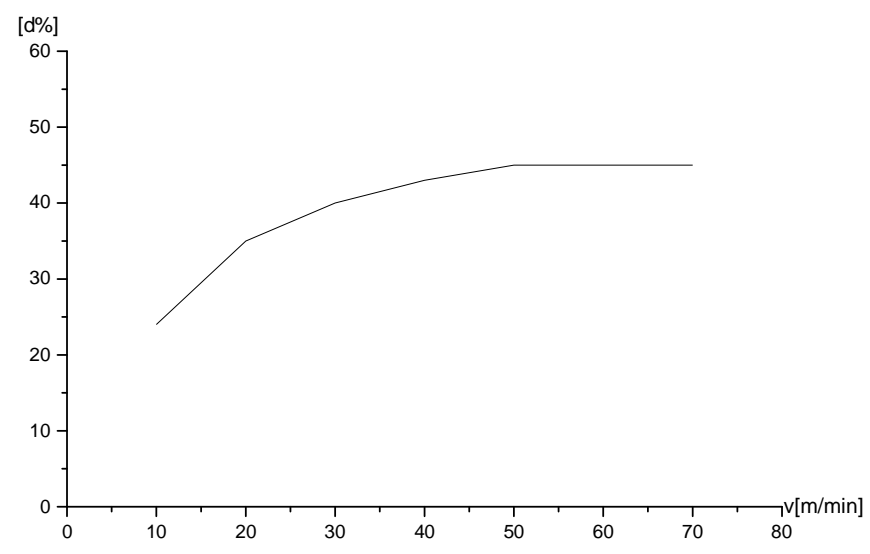

Sl. 6. Relativna procentualna ušteda snage u funkciji proizvodne brzine

Eksperiment je obavljen sa impederima čiji je prečnik $12 \mathrm{~mm}$. Kod feritnog impedera ferit je bio zvezdast prečnika $10 \mathrm{~mm}$, a kod novog FA impedera materijal je bio kvadratnog preseka $7 \times 7 \mathrm{~mm}$. Dužina feritnog impedera je iznosila $200 \mathrm{~mm}$ a novog impedera $150 \mathrm{~mm}$.

Zavarena cev, je za oba slučaja, testirana mehaničkim probama pod pritiskom na spljoštavanje. Var sa novim impederom i kod potpunog spljoštavanja nije se otvorio, što nije slučaj sa varom koji se dobio primenom feritnog impedera. Dešavalo se pri mnogim mehaničkim probama da prsne cev na osnovnom materijalu gde nema vara i to kod proba sa potpunim spljoštavanjem. Inače, var dobijen zavarivanjem sa novim FA impederom dobio je visoke ocene od Službe kontrole FAHOP po ISO standardu. 


\subsection{Primena kriterijuma za ocenu postignutih rezultata}

Dobijena ušteda $\mathrm{u}$ snazi primenom novog impedera omogućava da se može proizvoditi i znatno većim proizvodnim brzinama što rezultuje povećanjem produktivnosti tehnoloških linija za izradu čeličnih cevi.
Autori će radi ocene postignutih rezultata novog FA impedera koristiti prehodno navedena tri kriterijuma pri proizvodnji cevi prečnika $21,6 \mathrm{~mm}$.

Sl. 7 prikazuje zavisnost utrošene energije po toni cevi u funkciji brzine.

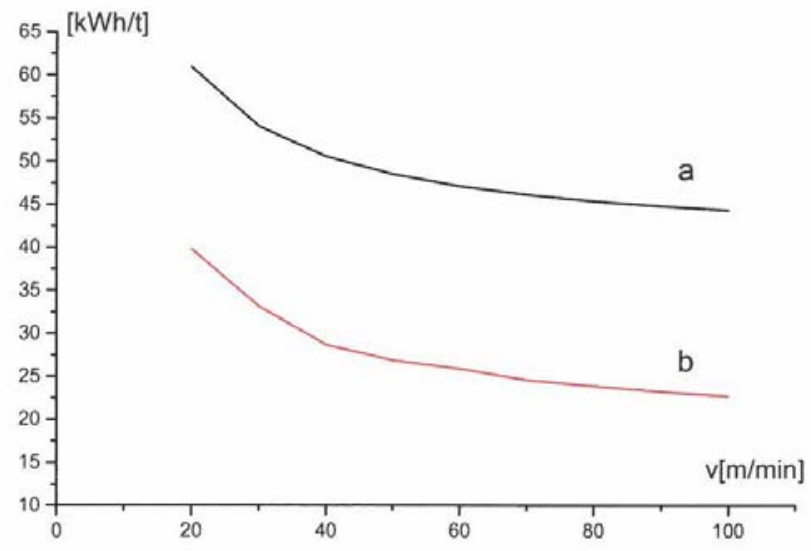

Sl. 7. Potrošnja energije po toni cevi u funkciji brzine proizvodnje (a-TDK feritni impeder, b-FA impeder)

Zavisnost toplotnog koeficijenta iz [6] je data na slici sl. 8 .

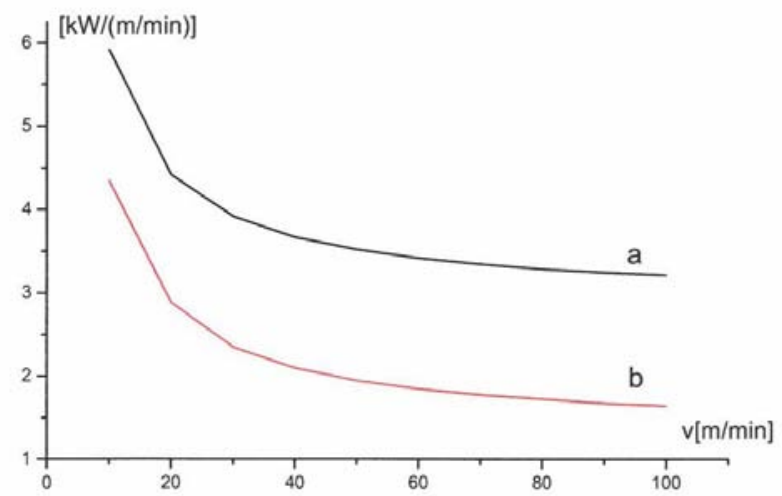

SI. 8. Toplotni koeficijent u funkciji proizvodne brzine (a-TDK feritni impeder, b-FA impeder) 
Grafik specifične snage iz [1] je predstavljen slikom sl.9.

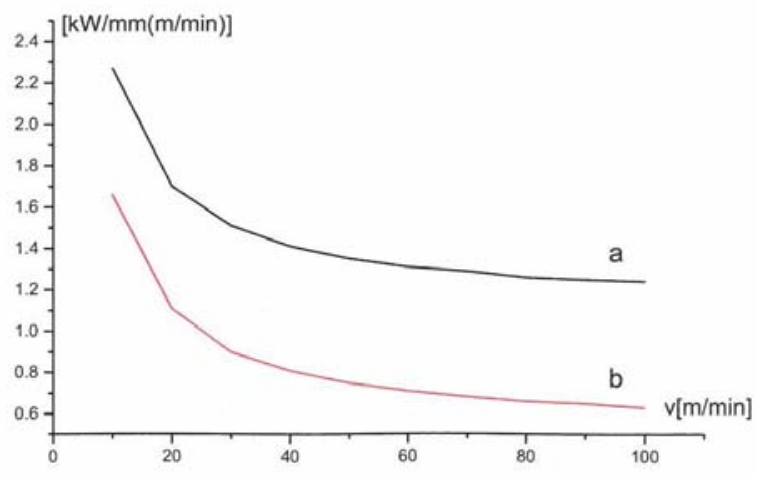

S1. 9. Specifična snaga u funkciji proizvodne brzine (a-TDK feritni impeder, b-FA impeder)

Krive "a" odgovaraju feritnom impederu, a "b" novom FA impederu. Zaključujemo da je novi impeder znatno efikasniji jer to potvrđuju napred navedena tri kriterijuma, od kojih se dva koriste u literaturi kao poznati, a jedan uvode autori rada kao originnalan i nov.

Pored pomenute energetske uštede od $45 \%$ primenom novog $\mathrm{FA}$ impedera, u odnosu na najbolji TDK feritni impeder, primenom navedena tri kriterijuma, svi navedeni kriterijumi daju dobru ocenu efikasnosti primene novog impedera. Takođe su autori, kroz svoja istraživanja došli do korisnog zaključka da je korisno zavarivati na brzinama većim od $40 \mathrm{~m} / \mathrm{min}$, kada se obezbeđuje optimalnost. Optimalnost se dobija kada vrednost iz (1) dostigne asimptotu, što isto važi i za ostale kriterijume. Autori iz [6] ne uočavaju ove zaključke već daju rezultate za brzine veće ili jednake 50 $\mathrm{m} / \mathrm{min}$.

Sl. 10 ilustruje fotografije originalnih unutrašnjih varova, tzv. provar, sa feritnim impederom i novim FA impederom. Prva od fotografija je dobijena feritnim impederom, a druga pomoću novog FA impedera. Unutrašnji var dobijen novim impederom je sa manjim nadvišenjima, uzaniji je i kontinualniji je, a mehaničke probe spljoštavanja ovu konstataciju još više potvrđuju time da je var znatno izdržljiviji.

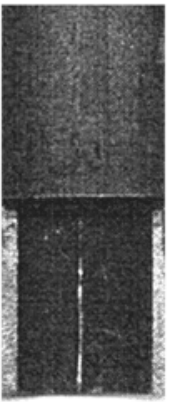

b)

SI. 10. Var u unutrašnjosti cevi za feritni (a) i FA impeder (b) 
Nov impeder sa FA magnetodielektrikom ćemo uporediti sa rezultatima datim u [6]. Tu su izloženi rezultati primene specijalnih impedera sa amorfnim folijama i $3 \%$ Si folijom upotrebljeni sa još feritnim impederom iz Japana.

Autori ovog rada u cilju preglednosti će prikazati uporedne karakteristike svojih naučnoistraživačkih rezultata i rezultata iz literature [6] kroz sređenu tabelu $T_{3}$. Primenom sva tri kriterijuma zaključuje se da je bolji naš nov FA impeder. Ušteda snage iz [6] iznosi 32\%, što u poređenju sa novim FA impederom od $45 \%$ daje zaključak da je rešenje autora ovog rada efikasnije za $41 \%$. Ovome treba dodati da je rešenje dato u ovom radu jeftinije od pomenutih.

Tabela 3. Prikaz rezultata uporednih kriterijuma zaTDK i nov FA impeder i rezultata iz [6]

\begin{tabular}{|l|c|c|c|c|}
\hline \multicolumn{1}{|c|}{ Kriterijum } & $\frac{\mathrm{kWh}}{\mathrm{t}}$ & $\frac{\mathrm{kW}}{\mathrm{mm}(\mathrm{m} / \mathrm{min})}$ & $\frac{\mathrm{kW}}{\mathrm{m} / \mathrm{min}}$ & $\begin{array}{c}\text { Dužina } \\
{[\mathbf{m m}]}\end{array}$ \\
\hline Materijal za impeder & 83,3 & 3,57 & 15 & 400 \\
\hline 3\% Si-folija & 57,11 & 2,45 & 10,3 & 400 \\
\hline Feritni - TDK imped. & 50 & 1,35 & 3,52 & 200 \\
\hline Magnedial. - FA imp. & 27 & 0,75 & 1,95 & 150 \\
\hline
\end{tabular}

Primenom novog impedera postižu se energetske uštede u odnosu na feritni impeder do $45 \%$, što opravdava rezultate istraživanja. Takođe, nov impeder daje uštedu i u odnosu na neke specijalne impedere iz [6], te se otvara jedna veoma korisna primena sa impederima od magnetodielektrika.

\section{ZAKLJUČAK}

Autori ovog rada su sebi postavili cilj da projektuju i istraže jedan nov impeder sa magnetodielektrikom koji će imati znatne energetske uštede $u$ snazi pri zavarivanju u odnosu na TDK feritni impeder. Na osnovu višegodišnjih eksperimentalnih istraživanja, među magnetodielektricima firme Fluxtrol, autori pronalaze kao originalan materijal Flixtrol A za izradu impedera i na taj način nastaje nov impeder.

Pokazano je i dokazano da primena novog impedera donosi znatne energetske uštede u poređenju sa feritnim impederima, kao i u poređenjima sa nekim specijalnim skupim impederima. Primenom poznatih kriterijuma i novouvedenog kriterijuma, utvrđuje se da nov impeder ima bolje performanse $u$ odnosu na feritni impeder.

Ako se izračuna godišnja ušteda, za našu referentnu cev prečnika $21,6 \mathrm{~m}$, čista finansijska ušteda je cca 350.000 \$. Postignuta ušteda u potrošnji električne energije od oko 45\% omogućava povećanje produktivnosti, odnosno proizvodne brzine čeličnih cevi, i do $90 \%$ što opravdava napore istraživača.

Iako su eksperimenti vršeni na cevnom generatoru, rezultati menjaju pogled na induktivnu metodu zavarivanja za opseg istraživanih dijametara cevi. Rezultati menjaju i vrednost sveukupnog koeficijenta iskorišćenja cevnih generatora za zavarivanje, gledano sa aspekta ulazne snage i snage koja se predaje samoj čeličnoj cevi u procesu VF induktivnog zavarivanja.

Autori rada prezentuju stručnoj i naučnoj javnosti novo rešenje impedera sa magnetodielektrikom tipa Fluxtrol A, koji u praksi 
donosi znate energetske uštede što rezultati eksperimenata potvrđuju. Energetske uštede stvaraju mogućnost povećanja brzine zavarivanja, a samim tim i proizvodnje čeličnih cevi, odakle sledi povećanje produktivnosti tehnoloških linija za izradu čeličnih cevi.

\section{LITERATURA}

[1] Šamov N. A., Lunin, V. I., Ivanov, N. V.: 'Vysokočastotnaja svarka metalov' (Mašinostroenie, Leningrad, 1977), str. 5-23.

[2] Guljajev D.: 'Soveršenstvovanie tehnologii proizvodstva i povišeniie kačestvo elektrosvarnyh trub' (Tehnika, Kiev, 1984), str. 86-116.

[3] Nemkov V. S., Demidovich V. B. (1988), Theory of induction heating, Energy Publ., St. Petersburg (In Rusian), str.. 6-30.

[4] Wright J. (1997), Principles of High Frequency Induction Tube Welding. Electronic Heating Equipement, Sumner Inc., str. 1-8.

[5] Wade J. (1990), Effective Utilisation of Magnetic Flux Concentrators in Induction Heating at Commercial Heat Treating Plant., Industrial Heating, Vol. LVI, No. 2, Feb.1989, Fluxtrol Manufacturing Inc., str. 14-16.

[6] Mitani K., Shibua-ku H., 'Impeder: 'How its Innovation and Design Impacts the Welding Processes'. The Eight Annual World Tube Congress, 912.11.1992, Chicago, Illinois, str. 35-53.

[7] Rudnev I. V.: 'Induction Heat Treatment' (Steel Heat Treatment Handbook, New York, Basel, Hong Kong, 1997), str. 1-27.
[8] Fluxtrol Manufacturing: 'Magnetic Flux Concentrators for High Frequency Induction Heating'. Fluxtrol Manufacturing, MI-USA, 1996, str. 1-45.

[9] Milićević M.: 'Avtomatičeskoe upravlenie processom indukcionnoi svarki trub s primeneniem mikro-EVM', $7^{\text {th }}$ Meždunarodnoja konferencija stran členov SEV i SFRJ po avtomatizacii proizvodstvenyh processov i upravlenija v černoi metalurgii, Sekcija II, 1988, Ždanov, SSSR, str. 1-10.

[10] Milićević M., Milićević V. (2001), Optimizacija energetskih parametara i kvaliteta VF induktivnog zavarivanja čeličnih cevi, XI Međunarodni simpozijum - Energetska elektronika Ee2001, 31.10. - 02.11.2001 god., Novi Sad, str. 4.

[11] Milićević M., Milićević V., Milićević T. (2004), MDM Impeder for Improvement of Parameters and Quality of HF Inductive Welding. $36^{\text {th }}$ International October Conference on Mining and Metallurgy, Bor, str. 531-537.

[12] TDK: 'TDK impeder core'. Technical documentation, Italy, 1999, pp. 1-37.

[13] 'Catalog Applications Guide', Electronic Heating Equipment, Inc., Impeders, Work Coils, Ferrite, Casing, 1998, Buckley-WA, str. 1-20.

[14] Milićević M., The Application of a New Formula of Nakaoka Coefficient in HF Inductive Welding, Journal of Mechanical Engineering, Faculty of Mechanical Engineering Ljubljana, Slovenia, no. 7-8, vol. 56, 2010, str. 483-485. 